\title{
Russian periphery is dying in movement: a cohort assessment of internal youth migration in Central Russia
}

\author{
Ilya Kashnitsky (10
}

Published online: 22 November 2018

(C) The Author(s) 2018

\begin{abstract}
This paper investigates youth migration in Russia at the sub-regional level of administrative division. The aim of the research is to assess the volume of internal youth migration in cohort perspective. The task is only doable with the use of census data, which not only makes it possible to conduct research at the sub-regional level, but also provides much more accurate information on youth migration than the current migration record. I utilize cohortcomponent analysis to study sub-regional population dynamics. As mortality is quite insignificant at young ages, most of the change in cohort size is caused by migration. My estimates show that during the last intercensal period, 2003-2010, up to $70 \%$ of youth cohorts have left the regional periphery after graduating from school, and there was no substantial return to the demographically depleted periphery in the young working ages.
\end{abstract}

I. Kashnitsky ( $\square)$

National Research University Higher School of

Economics, Moscow, Russia

e-mail: ilya.kashnitsky@gmail.com;

ikashnitsky@hse.ru;

i.kashnitsky@rug.nl

URL: https://ikashnitsky.github.io

I. Kashnitsky

University of Groningen/NIDI, Groningen, The

Netherlands
Keywords Youth migration · Periphery depopulation · Rural demographics · Cohort migration studies $\cdot$ Cohort-component analysis $\cdot$ Maps of population

\section{Introduction}

Demographic history of every population is imprinted in its population structure. Population structures reveal the long-lasting influence of demographic processes and can be used to back-track these processes (Wilson et al. 2013). The role of migration in population replacement (Ediev et al. 2014; Filipov and Schuster 2010; Wilson et al. 2013) and polarizing the spatial pattern of population aging (Alho 2008; Franklin 2014; Gutiérrez-Posada et al. 2018; Sabater et al. 2017) is widely debated and acknowledged. Usually the role of migration as a factor of immense importance is noticed at the level of countries, i.e. for international migration (Coleman 2006; Wilson et al. 2013). This main focus on international migration is caused primarily by the quality and availability of data. Although, the population redistribution at the sub-national level may lead to much greater demographic consequences (Franklin 2003; Rees et al. 2013; Van Der Gaag and Van Wissen 2001).

At local level migration is the main factor causing substantial variation in population compositions 
(Champion et al. 1998; Plane et al. 2005; Rees et al. 2017). Of course, there is always some diversity in the levels of fertility and mortality, which result in quite a diverse picture at a higher geographical level, but they cannot explain the sharp differences between municipalities within regions. Usually the differences in fertility and mortality at the sub-regional level are quite moderate. Thus, most of the spatial variance of demographic structures at the sub-regional level is attributed to migration (Champion 1992; Johnson et al. 2005). Migration is always highly selective on age. Age selectiveness of migration was already noted in Ravenstein's "Laws of migration" (1885), and the term "differential mobility" was firstly introduced by Thomas (1938). Empirical support for age selectiveness has been provided by Pittenger (1974), Bracken (1976), Castro and Rogers (1983), Bailey (1993), Millington (2000), Xu (2014) and many others.

The most common feature of virtually every age profile of migration intensities is a prominent peak at young ages (Wilson 2010), when people take their first independent migration decisions (Dustmann and Glitz 2011; Patiniotis and Holdsworth 2005; Thissen et al. 2010). With the global rise of educational attainment (Chudnovskaya and Kolk 2017; Esteve et al. 2016) these decisions are increasingly linked with educational strategies (Cooke and Boyle 2011; Mulder and Clark 2002; Smith et al. 2014). The importance of university structure makes the pattern of this "studentage" migration rather unique (Van Mol and Timmerman 2014). The quality of universities matter a lot in directing these particular migration flows (Abbott and Schmid 1975; Ciriaci 2014). Sometimes these university centers of migration attraction are located far from the main metropolitan areas (Cooke and Boyle 2011). Thus, the disproportionately rapid growth of the exclusively university centers causes the out-migration of the graduates in search of jobs later on (Baryla Jr and Dotterweich 2001; Beine et al. 2014). At this stage in migrants' life course economic well-being of regions also a significant influence on migration decisions (Findlay 2011; Venhorst et al. 2011).

In this paper I focus primarily on migration of the youths because their movement determines the largest changes in the demographic structures. Relocation of young people change the basis of the demographic structure determining the mode of the demographic development for the future generations. This paper explores population structures at the municipal level in
Russia. The aim of the analysis is to shed some light on the extent to which internal migration of youths shape demographic structures.

In Russia the peak intensity of migration happens rather early, at ages 17-18, at the turning point of graduation from school and admission to universities (Kashnitsky et al. 2016). This is important since empirical investigation of Bernard (2017) revealed a tight association between the age at first move with the completed migration rate, the earlier people migrate first, the more mobile they will be throughout their lifespan.

One very important question, is whether the rural areas, depleted by youth migration at student ages, succeed in returning back their youths. There is evidence of both increased return to the periphery (Ní Laoire 2007; Rérat 2014) and youth exodus without subsequent return (Domina 2006; Johansson 2016; Rauhut and Littke 2016). I address this question in the present study to find no significant return periphery (see "Do the young movers come back later?" section). This result is rather expected, since the previous qualitative studies showed a clear desire of the youth to flee the periphery for good both at upperschool and student ages (Florinskaya 2017; Florinskaya and Roshchina 2006).

The present analysis of migration patterns of the youth at the sub-regional level allows us to draw conclusions about the present-day and future demographic development of Russian periphery. The paper is organized as follows. First the regional and subregional context of Russia is disclosed in "Background" section. Methodology and data are discussed in "Methods and data" section. The discrepancy between census and registration data on migration is shown in "Statistics discrepancy: census data versus current migration record" section. My estimates of cohort migration intensities in the last intercensal period are provided in "Estimation of internal youth migration" section. The question of return migration to the periphery is addressed in "Do the young movers come back later?" section. The concluding remarks are given at the very end of the paper ("Conclusions and discussion" section), and the unclear future of the periphery is discussed. 


\section{Background}

There are four levels of administrative division in Russia: federal districts, regions, municipalities, and settlements or city districts. Federal districts are only used for better government of the huge Russian territory. Statistical data is easily available for federal districts, but the size of these units is too large to conduct any meaningful spatial analysis. Usually demographic research addressing the issues of spatial diversity is held at the level regions. The majority of official statistics is available for the level of regions.

Region is the basic unit of federal administrative division. Every region has limited self-government which could be roughly compared with the legal status of states in the US or the bundeslands of Germany. Russian regions vary a lot by area and population size. Generally, regions tend to be smaller and more densely populated in the European part of the country. To put Russian regions in a context consider comparing them to the European administrative division system, NUTS (EuroVoc 2017). The area of the largest Russian region, Yakutia, is more than 5 times bigger than France. And the most populated region, Moscow, is bigger than Belgium, Portugal or Greece. On average, Russian region is larger than European country (NUTS 0) whereas its population size is comparable with a NUTS 2 level region. When only the historically populated Central Federal District is considered, regions could be placed between 1 and 2 on the NUTS scale. Municipalities are on average smaller than NUTS 3 level.

The most suitable level of administrative division for researching on core-peripheral issues is the level of municipalities. On average region in Russia consists of 28 municipalities. This rather fine fragmentation gives a proper distinction between regional centers and the inner periphery. There are two main difficulties in working with the data at the municipal level. First, very limited data is available for this level; the reliable estimates of population age structures are only present in census data. Second, administrative division is quite unstable. Numerous changes in the delimitation of administrative units happen during every intercensal period, which becomes an issue for a researcher who struggles to link the data of adjacent censuses and compare longer time periods.

Unlike regional level, where reshaping of boundaries is quite a rare and easily trackable phenomenon, changes in administrative division at municipal level happen too often and are quite challenging to account for. These changes may appear in multiple forms. There are two types of municipalities in Russia: municipal districts (rural units) and urban districts. The least problematic type of change in administrative division involves a switch of a unit's status, from a municipal district to an urban district, or vice versa. Only in this case no recalculation is required. More often neighboring units are merged together. This is still a simple case to treat, since the only task is to sum up two populations. A more difficult case happens when municipalities are split in finer units, e.g. a local town gets separated from its surrounding area. Since the exact population structures are not available before the separation, the only solution that does not require any assumptions is to keep the units merged in the analysis. Generally, linking adjacent municipal structures, one has to either aggregate data or impose assumptions on relative population dynamics in the two involved units. The trickiest type of change happens when part of one municipality is transferred to the neighboring one. In such a case one cannot avoid introducing more or less arbitrary assumptions of population dynamics in the transferred population.

There is also a specific Russian phenomenon of new administrative units' sudden "appearance" (Karachurina 2014; Karachurina and Mkrtchyan 2015). There were quite a lot of cities and areas with restricted access in the Soviet Union, that usually hosted various secret objects (military objects, army factories, scientific laboratories). After the fall of the USSR such cities began to appear out of nowhere in the official statistics and on the maps. Not all the former closed areas were opened at the same time. Their disclosure mostly happened during the first intercensal period (1990-2002), right after the fall of the USSR, but the latest such areas, mainly located in Urals, were only disclosed in 2004.

In the paper I discuss extensively center-peripheral differences within regions. The distinction here is quite arbitrary and is based on rather gradual centerperipheral gradient. Depending on the size of the regional capital and it's migratory attractiveness, the center can span over several neighboring municipalities forming an urban agglomeration. Some studies aimed at exploring the distances if regional centers' influence (Karachurina and Mkrtchyan 2015). But these attempts cannot provide an objective basis for 
classification of regional centers and inner peripheries. I argue that migration attractiveness of the regional center can proxy intra-regional center-peripheral gradient.

\section{Methods and data}

To estimate the volume of internal youth migration in birth cohorts I employ cohort-component analysis (Bogue 1982; Preston et al. 2001; Wunsch and Termote 1978) which was also known in Russia as the method of age-shift (Moiseenko 2004; Zayonchkovskaya 1991). The idea of the method is quite simple: people can survive, die or move, not vanish. So one can evaluate population dynamics, migration and mortality, of a certain cohort during the intercensal period by the comparison of corresponding age groups at the time of two adjacent censuses. Once mortality is accounted for, the rest of the change in cohort size is attributed to migration (Filipov and Schuster 2010).

The prime data sources of this study are the 2002 and 2010 Russian Censuses. I also use the current statistical records of mortality to assess its impact on cohort dynamics and migration records to estimate migration intensities of youths and compare them to the migration evaluations based on census data. Combining the two sources of migration data and comparing them proves to be very useful (Raymer et al. 2011).

Why is census data considered as primary? The first and the main reason for such a choice is that only census data allows to analyze spatial mobility of the population at the sub-regional level. Other demographic data on population movement with detailed age distribution is not available for this fine level. And I am specifically interested in revealing core-peripheral patterns of internal youth migration.

The second very important reason is associated with the problems of current migration record that follow the fall of the Soviet Union. The liberalization of the rules of tabulation by the place of residence in Russia caused huge inaccuracy in the migration statistics (Choudinovskikh 2004). Naturally, the most problematic age group proved to be the youth, especially the so called "student ages". The peak of migration intensity in Russia usually happens at the age of 17-19 (Karachurina and Mkrtchyan 2018;
Kashnitsky et al. 2016). Some positive changes in migration record system happened only in 2011, leaving migration statistics for the intercensal period quite unreliable. It turns out that migration statistics used to underestimate migration intensity of youths at the regional level, capturing less than a half of the real flow (Kashnitsky et al. 2016).

Due to the difficulties of overcoming the numerous changes in municipal boundaries, I limited the area of sub-regional research within the 18 regions of Central Federal District of Russia (Fig. 1), where the administrative division is relatively mature due to the long history of inhabitancy. In the end I analysed internal migration of youths in 505 municipalities, where 43 changes in municipal structure happened in the last intercensal period, 2003-2010.

\section{Statistics discrepancy: census data versus current migration record}

For the selected set of regions I compared the two main sources of migration statistics, censuses and current migration record using cohort-component analysis (Table 1).

Our previous research (Kashnitsky 2015; Kashnitsky et al. 2016) and the existing literature (Choudinovskikh 2008, 2010) indicate the exceptionally big error of the current migration record in capturing migration at the "student ages". The analysis presented here is aimed to check the discrepancy between census and current statistics at sub-regional level and evaluate the volume on internal youth migration based on the more reliable census data.

The cohort-component method was applied to two generations, each consisting of 5 birth cohorts. The first one is the present-day cohort of "student ages", born in 1988-1992, who were in the ages of 18-22 at the time of the 2010 Census. The second considered generation was born in 1980-1984, and its representatives were in "student ages" at the time of the 2002 Census.

The discrepancy (red color in the Table 1) between the censuses (green) and the current statistical record (blue) is striking. If census data is assumed as the primary source, and there are good reasons for such a choice, it turns out that current statistical record failed to register $80 \%$ of the change in cohort $1988-1992$ in Central Federal District (CFD). Intercensal age-shift 


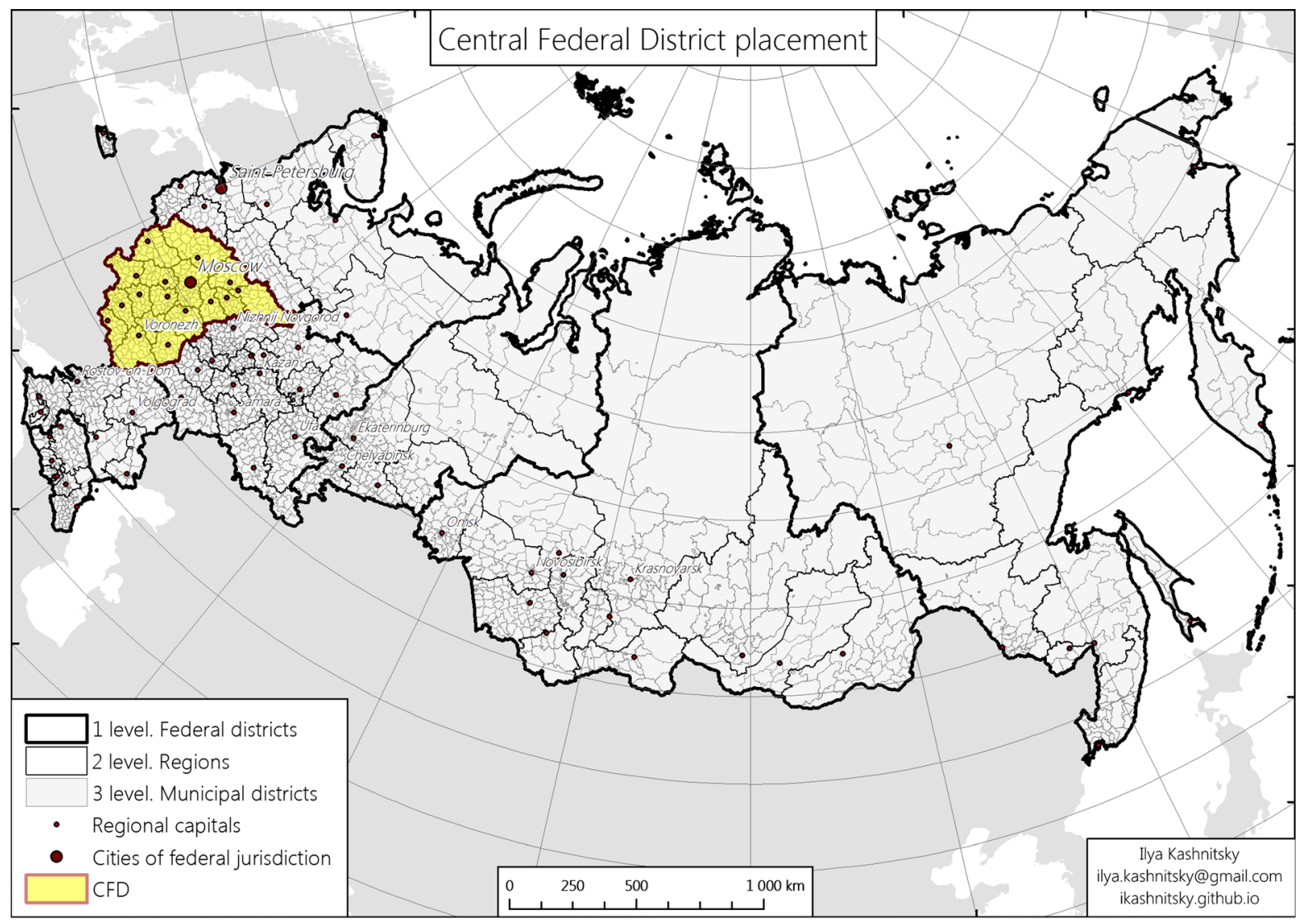

Fig. 1 Reference map of Russian administrative division system; the location of Central Federal District is highlighted

estimate saw an $17.9 \%$ increase in the size of 1988-1992 birth cohort, whereas official statistics recorded on a rolling basis only saw a $3.5 \%$ increase; thus, 14.4 percentage point of the cohort growth came unaccounted by the current statistical record (the last, "Unexplained change", column in the Table 1). In some regions even the direction of change between the two data sources varied. For example, in Vladimir region current statistics registered a decrease of $1.6 \%$ in the 1988-1992 birth cohort, while censuses revealed an increase of $2.2 \%$. The case of Vladimir region is not unique; similar misreports are present for Kaluga, Ryazan, Smolensk and Tula regions (Fig. 2).

Summing up, the current statistical record was unable to capture reliably the dynamics of youth cohorts during the intercensal period 2003-2010. The official migration statistics are not suitable for researching on youth migration. Of course, census data is not perfect and has its limitations (Andreev 2012), but for the purpose of migration study of youths it is definitely the most reliable source of data available; the outlined comparison with current statistical record illustrates the point.

\section{Estimation of internal youth migration}

To assess the volume of youth intra-regional migration, I used data for 18 regions of the Central Federal District (CFD) of Russia and applied the survival method for 5 one-year birth cohorts (1988-1992). Each of these cohorts has experienced the 18-years peak of migration activity during the period between the 2002 and 2010 Censuses. At the time of the 2002 Census they were 10-14. Naturally, during the intercensal period, they grew older and reached the "student" ages, 18-22, by the 2010 Census.

The data allows to look at the intercensal cohort losses of regional periphery by every municipality. These losses are almost entirely attributed to 
Table 1 Cohort-component analysis of the birth cohorts 1988-1992 and 1980-1984 during the intercensal period 2003-2010

\begin{tabular}{|c|c|c|c|c|c|c|c|c|c|c|}
\hline & $\begin{array}{l}\text { Cohort size } \\
\text { in 2002, } \\
\text { thousands }\end{array}$ & $\begin{array}{l}\text { Cohort size } \\
\text { in } 2010, \\
\text { thousands }\end{array}$ & $\begin{array}{l}\text { Change by } \\
\text { census, } \\
\text { thousands }\end{array}$ & $\begin{array}{l}\text { Deaths in } \\
2003-2010, \\
\text { thousands }\end{array}$ & $\begin{array}{l}\text { Migration in } \\
2003-2010, \\
\text { thousands }\end{array}$ & $\begin{array}{l}\text { Change by } \\
\text { stat record, } \\
\text { thousands }\end{array}$ & $\begin{array}{l}\text { Discrepancy, } \\
\text { thousands }\end{array}$ & $\begin{array}{l}\text { Change in } \\
\text { cohort size by } \\
\text { census, \% }\end{array}$ & $\begin{array}{l}\text { Change in } \\
\text { cohort size by } \\
\text { stat record, \% }\end{array}$ & $\begin{array}{l}\text { Unaccounted } \\
\text { cohort change, } \\
\% \text { points }\end{array}$ \\
\hline \multicolumn{11}{|c|}{ Cohort $1988-1992$} \\
\hline Belgorod region & 106.8 & 112.1 & 5.4 & 0.7 & 5.2 & 4.6 & 0.8 & 5.0 & 4.3 & 0.8 \\
\hline Brynsk region & 99.8 & 91.0 & -8.7 & 0.7 & -2.1 & -2.8 & -6.0 & -8.7 & -2.8 & -6.0 \\
\hline Vladimir region & 99.5 & 101.7 & 2.2 & 0.9 & -0.7 & -1.6 & 3.9 & 2.2 & -1.6 & 3.9 \\
\hline Voronezh region & 156.4 & 174.2 & 17.8 & 1.2 & 5.3 & 4.0 & 13.8 & 11.4 & 2.6 & 8.8 \\
\hline Ivanovo region & 74.0 & 79.7 & 5.7 & 0.6 & 0.6 & 0.0 & 5.7 & 7.7 & 0.0 & 7.7 \\
\hline Tver' region & 97.3 & 91.9 & -5.5 & 0.9 & -0.8 & -1.7 & -3.8 & -5.6 & -1.7 & -3.9 \\
\hline Kaluga region & 70.3 & 71.3 & 1.0 & 0.6 & -1.3 & -1.9 & 2.9 & 1.5 & -2.7 & 4.1 \\
\hline Kostroma region & 51.4 & 44.4 & -7.0 & 0.4 & -1.4 & -1.9 & -5.1 & -13.6 & -3.6 & -10.0 \\
\hline Kursk region & 84.4 & 74.4 & -10.0 & 0.6 & -0.6 & -1.2 & -8.8 & -11.9 & -1.4 & -10.5 \\
\hline Lipetsk region & 82.3 & 77.8 & -4.5 & 0.6 & -1.6 & -2.3 & -2.2 & $-\mathbf{5 . 5}$ & -2.8 & -2.7 \\
\hline MOSCOW & 521.5 & 829.8 & 308.3 & 3.3 & 63.0 & 59.6 & 248.7 & 59.1 & 11.4 & 47.7 \\
\hline Moscow region & 401.8 & 512.7 & 110.9 & 3.5 & 33.9 & 30.4 & 80.5 & 27.6 & 7.6 & 20.0 \\
\hline Orel region & 58.0 & 56.1 & -1.8 & 0.4 & -0.2 & -0.6 & -1.3 & -3.2 & -1.0 & -2.2 \\
\hline Ryazan region & 79.3 & 82.6 & 3.3 & 0.7 & 0.2 & -0.6 & 3.9 & 4.2 & -0.7 & 4.9 \\
\hline Smolensk region & 70.5 & 71.7 & 1.2 & 0.6 & -1.2 & -1.8 & 3.0 & 1.7 & -2.6 & 4.3 \\
\hline Tambov region & 80.0 & 75.8 & -4.2 & 0.5 & -1.2 & -1.8 & -2.5 & -5.3 & -2.2 & -3.1 \\
\hline Tula region & 100.6 & 102.1 & 1.5 & 0.8 & -0.7 & -1.5 & 3.1 & 1.5 & -1.5 & 3.0 \\
\hline Yaroslavl region & 86.4 & 86.7 & 0.2 & 0.6 & 2.5 & 1.9 & -1.7 & 0.3 & 2.2 & -1.9 \\
\hline CFD TOTAL & 2320.3 & 2736.0 & 415.7 & 17.8 & 98.8 & 81.1 & 334.6 & 17.9 & 3.5 & 14.4 \\
\hline \multicolumn{11}{|c|}{ Cohort 1980-1984 } \\
\hline Belgorod region & 115.2 & 121.1 & 6.0 & 1.6 & 7.4 & 5.7 & 0.3 & 5.2 & 5.0 & 0.2 \\
\hline Brynsk region & 100.0 & 98.1 & -1.9 & 2.2 & -2.6 & -4.8 & 2.9 & -1.9 & -4.8 & 2.9 \\
\hline Vladimir region & 118.9 & 112.1 & -6.8 & 3.0 & -0.7 & -3.8 & -3.0 & -5.7 & -3.2 & 2.5 \\
\hline Voronezh region & 178.9 & 178.8 & -0.1 & 3.6 & -1.1 & -4.7 & 4.6 & 0.0 & -2.6 & 2.6 \\
\hline Ivanovo region & 90.1 & 80.9 & -9.2 & 2.2 & -1.1 & -3.3 & -5.9 & -10.2 & -3.7 & 6.6 \\
\hline Tver' region & 104.6 & 103.5 & -1.1 & 3.2 & 1.1 & -2.1 & 1.1 & -1.0 & -2.1 & 1.0 \\
\hline Kaluga region & 79.4 & 80.5 & 1.1 & 1.7 & 0.6 & -1.1 & 2.2 & 1.3 & -1.4 & 2.7 \\
\hline Kostroma region & 56.4 & 52.2 & -4.2 & 1.3 & -1.5 & -2.8 & -1.4 & -7.5 & $-\mathbf{5 . 0}$ & 2.5 \\
\hline Kursk region & 86.5 & 82.3 & -4.2 & 1.7 & -2.8 & -4.5 & 0.2 & -4.9 & -5.2 & 0.3 \\
\hline Lipetsk region & 83.9 & 89.7 & 5.8 & 1.8 & 0.8 & -1.0 & 6.8 & 6.9 & -1.2 & 8.1 \\
\hline MOSCOW & 852.7 & 1044.0 & 191.3 & 13.9 & 74.6 & 60.7 & 130.6 & 22.4 & 7.1 & 15.3 \\
\hline Moscow region & 550.2 & 603.8 & 53.6 & 13.2 & 84.4 & 71.2 & -17.6 & 9.7 & 12.9 & 3.2 \\
\hline Orel region & 63.2 & 57.7 & -5.5 & 1.2 & -1.7 & -3.0 & -2.6 & -8.8 & -4.7 & 4.1 \\
\hline Ryazan region & 90.8 & 84.9 & -6.0 & 2.3 & -0.5 & -2.9 & -3.1 & -6.5 & -3.1 & 3.4 \\
\hline Smolensk region & 80.8 & 78.2 & -2.6 & 2.1 & -2.3 & -4.4 & 1.8 & -3.2 & -5.4 & 2.2 \\
\hline Tambov region & 79.8 & 77.2 & -2.5 & 1.6 & -4.9 & -6.5 & 3.9 & -3.2 & -8.1 & 4.9 \\
\hline Tula region & 119.9 & 118.3 & -1.6 & 3.3 & 0.2 & -3.1 & 1.5 & -1.4 & -2.6 & 1.2 \\
\hline Yaroslavl region & 106.7 & 98.8 & -7.9 & 2.1 & 2.8 & 0.7 & -8.6 & -7.4 & 0.7 & 8.1 \\
\hline CFD TOTAL & 2958.2 & 3162.2 & 204.0 & 62.0 & 152.5 & 90.5 & 113.6 & 6.9 & 3.1 & 3.8 \\
\hline
\end{tabular}

migration. Changes in cohort sizes due to mortality at the ages 10-22 are less than $1 \%$ (Fig. 3). Mortality at the young ages is so low that there is ultimately no risk in interpreting the intercensal changes of the cohort sizes as the migration balance.

The significant difference between mortality probability and mortality coefficient for the young cohorts is a clear indicator of migration attractiveness of CFD. The positive migration balance of CFD at the young ages changed the denominator used for the calculation of mortality coefficient comparing to the denominator used for mortality probability, the initial cohort sizes at the 2002 Census. The total population of CFD has grown only by $1.1 \%$ during the intercensal period, while the growth in the 1988-1992 birth cohort was $17.9 \%$. I conclude that the impact of mortality is negligible for the cohorts under consideration.

The pattern of internal youth migration in CFD revels a massive redistribution of young population at the municipal level (Fig. 4b). Up to $70 \%$ of the youths in the 1988-1992 birth cohort leave the periphery after the school graduation. The leader of this loss is the remote inner periphery of Kostroma region, which is located furthest from Moscow and far away from the regional capital. In contrast, the situation in Tula region, which is located much closer to Moscow and is more compact itself, is not so dramatic - there are hardly any municipalities that lost more than a quarter of the student-age population.

To feel the scale of this population loss, one can compare it to the much more moderate change in the size of the whole population of districts and cities (Fig. 4a). Urbanization in Central Russia is still occurring rapidly. Urban districts with population of more than 100 thousand gained $6.1 \%$ while the rest of the municipal level units, the inner periphery, lost on average $5.0 \%$ of their total population. 
Fig. 2 Change in cohort sizes of 1988-1992 and 1980-1984 birth cohorts in the regions of CFD in 2003-2010, the discrepancy between estimates based on census data and current statistical record. Source: Censuses of 2002 and 2010, current record of migration and mortality

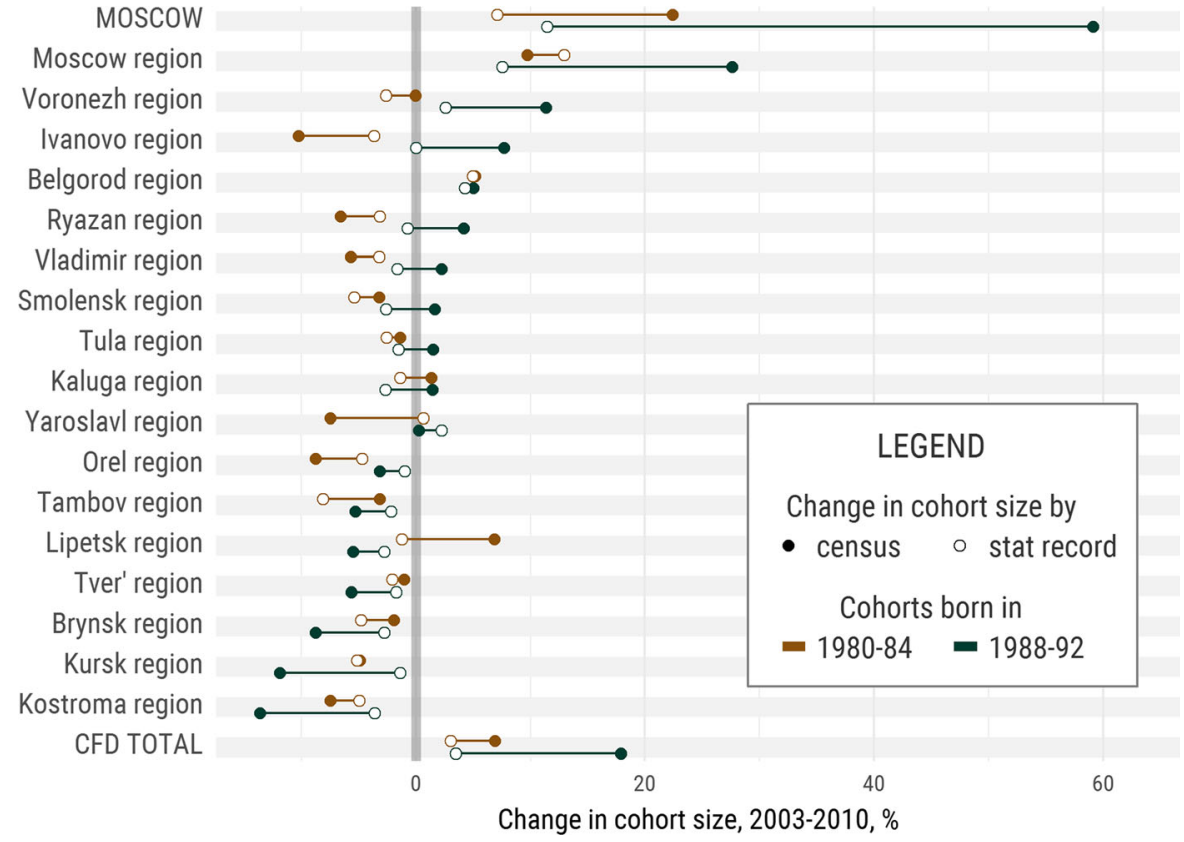

Do the young movers come back later?

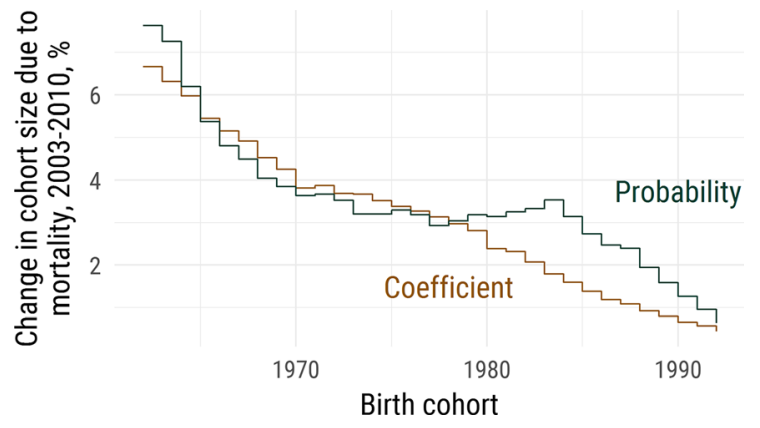

Fig. 3 Mortality impact on the cohorts' size during the 2003-2010 intercensal period, Central Federal District. Source: 2002 and 2010 Censuses, current statistical record of mortality (2003-2010)

Only big cities tend to attract the young movers. In the majority of regions only the regional center is attractive enough for the young, since all other cities are relatively small. Just imagine the future of a population where only $30 \%$ of the youth are willing to stay. The demographic development of hinterland does not seem to be sustainable. The research for the previous intercensal in Russia, 1989-2002, showed that up to $40 \%$ of school graduates had been leaving regional periphery in the search of better opportunities (Karachurina and Mkrtchyan 2015; Mkrtchyan 2013). My estimates demonstrate that the depletion of Russian hinterland is becoming more and more severe.
It is natural for the young to move from the periphery in search for education and better life opportunities. But the crucial question is whether the young movers return back to the periphery. Demographic prospects of the rural areas are not so miserable if there is a compensating return migration to the periphery. There are several conceptions of life-cycle migration describing the balance of migration between periphery and center though the lifespan of cohorts. One of the popular explanatory frameworks is the escalator region concept by Fielding (1989, 1993), which was persuasively supported with evidence from some developed countries. A key factor here is the stage of urbanization. The migration balance between core and periphery is quite similar to the urbanization/suburbanization balance, but in Russia urbanization has not finished yet. Apart from the usual lag in demographic development, there is also a deep agricultural crisis in rural areas after the fall of the Soviet Union. The only analogue of escalator region migration in Russia is the life-cycle population exchange between the Far North and the Southern regions, in which young workers migrate to the North in search of higher income, and the retirees move to the South fulfilling the long-lasting dream of living in warm climate. But this phenomenon is beyond the scope of present 
A

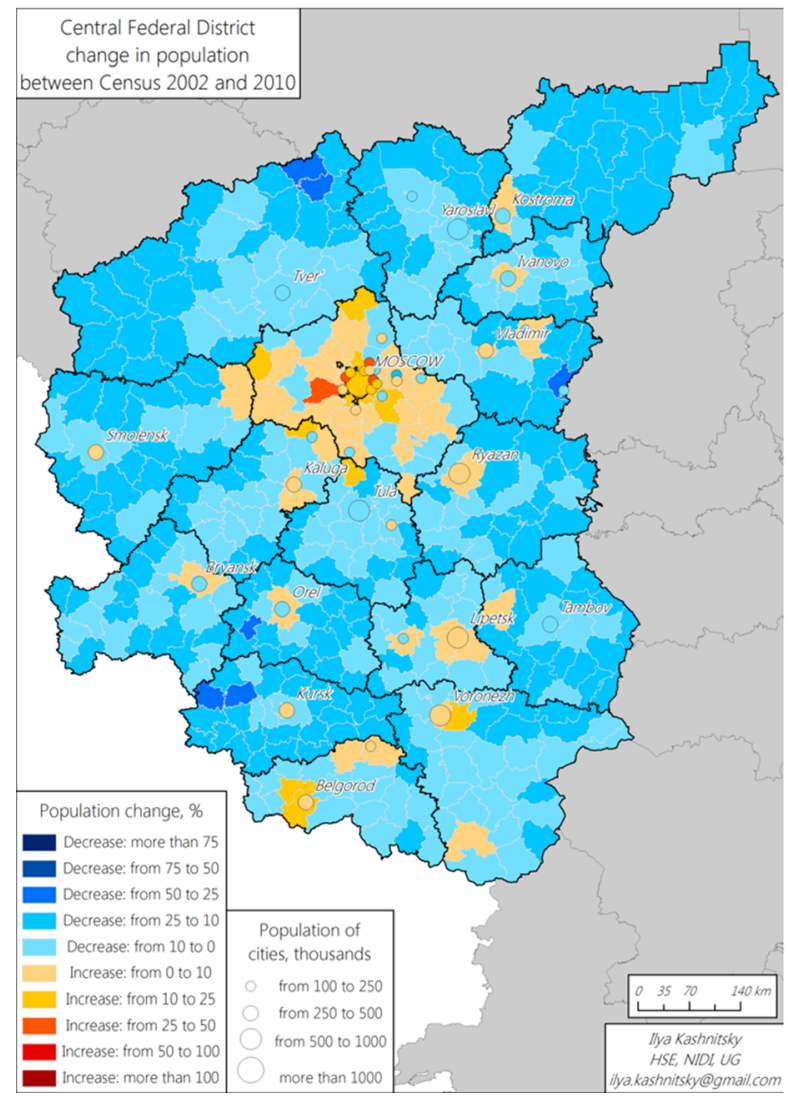

B

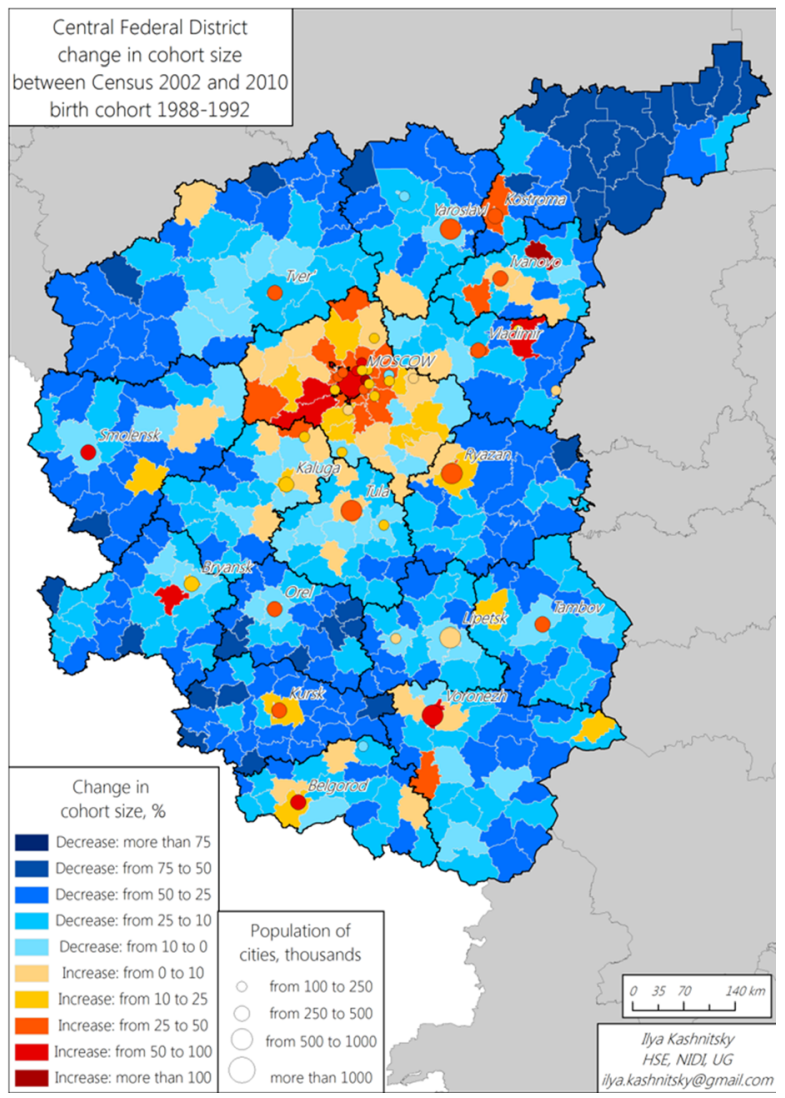

Fig. 4 Central Federal District of Russia, change during 2003-2010, \%: a total population change; b change in the 1988-1992 birth cohort size. Source: 2002 and 2010 Censuses

research. The whole concept of life-cycle migration does not work at the inter-regional level in modern Russia. Hence, I expect to see no significant return of the "post-student" aged population to the inner periphery.

In order to assess the volume of the return movement of the youths to the periphery, I chose to study the intra-regional migration of the 1980-1984 birth cohort (Fig. 5a); these people were in the "student ages" at the time of the 2002 Census and grew into young working ages by the 2010 Census. As I do not have long time series to trace the real cohorts through the "student ages" and on to the young working ages, I am forced to make some synthetic cohort assumptions due to the data limitations. Thus, I apply survival ratios of the 1980-1984 birth cohort in the 2003-2010 intercensal period to the current "students"-the 1988-1992 birth cohort. In other words, I project the size of the 1988-1992 birth cohort for the next 8 years, till 2018, assuming that their migration rate would be the same as for the 1980-1984 cohort in the 2003-2010 period. This is quite a rough assumption, but it helps to understand the possible pattern of return migration for the contemporary young generations.

Figure $5 \mathrm{~b}$ gives the idea about the possible return rate of the young movers from periphery. There is no massive return. True, some peripheral districts experience a slight influx of young migrants. But let us not forget that this inflow of migrants follows a huge outmigration earlier. The most depressed municipalities continue to sustain serious losses of young population. The regional centers in the CFD face a surplus of "high school graduates", but they experience a slight loss of young population in the "post-student ages" (Fig. 5a).

The projection exercise for the 1988-1992 birth cohort (Fig. 5b) reveals that the impact of inter- 
A

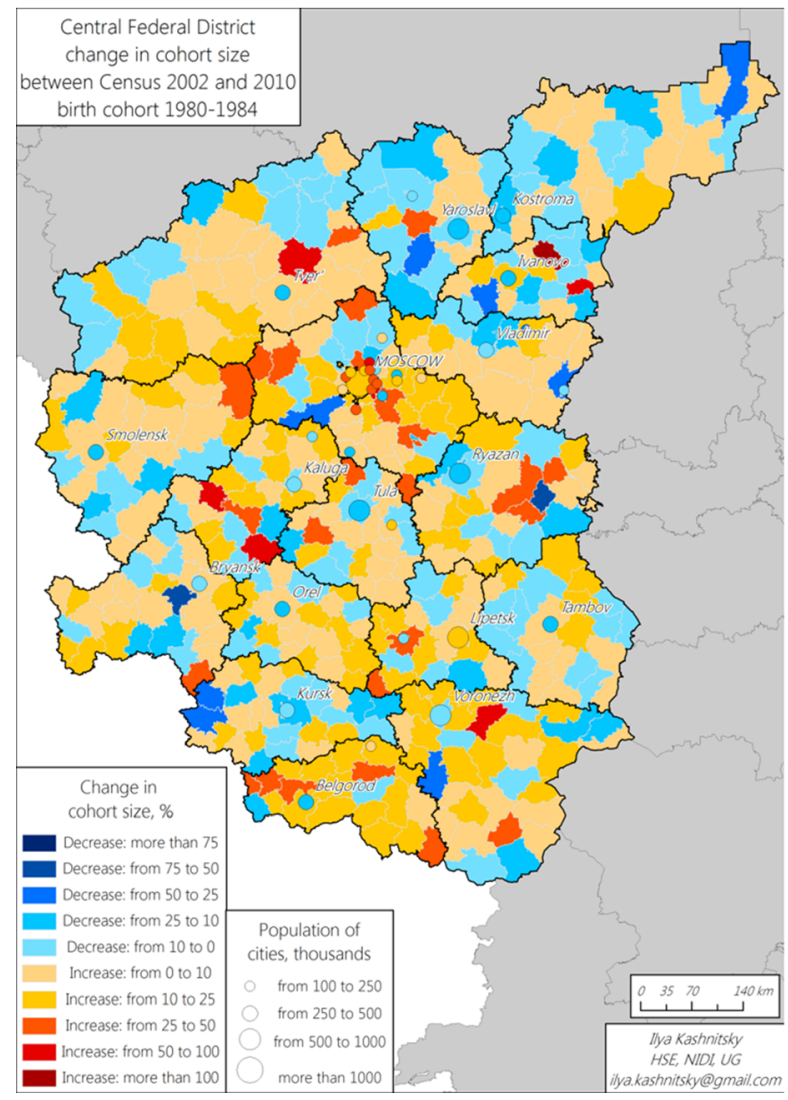

B

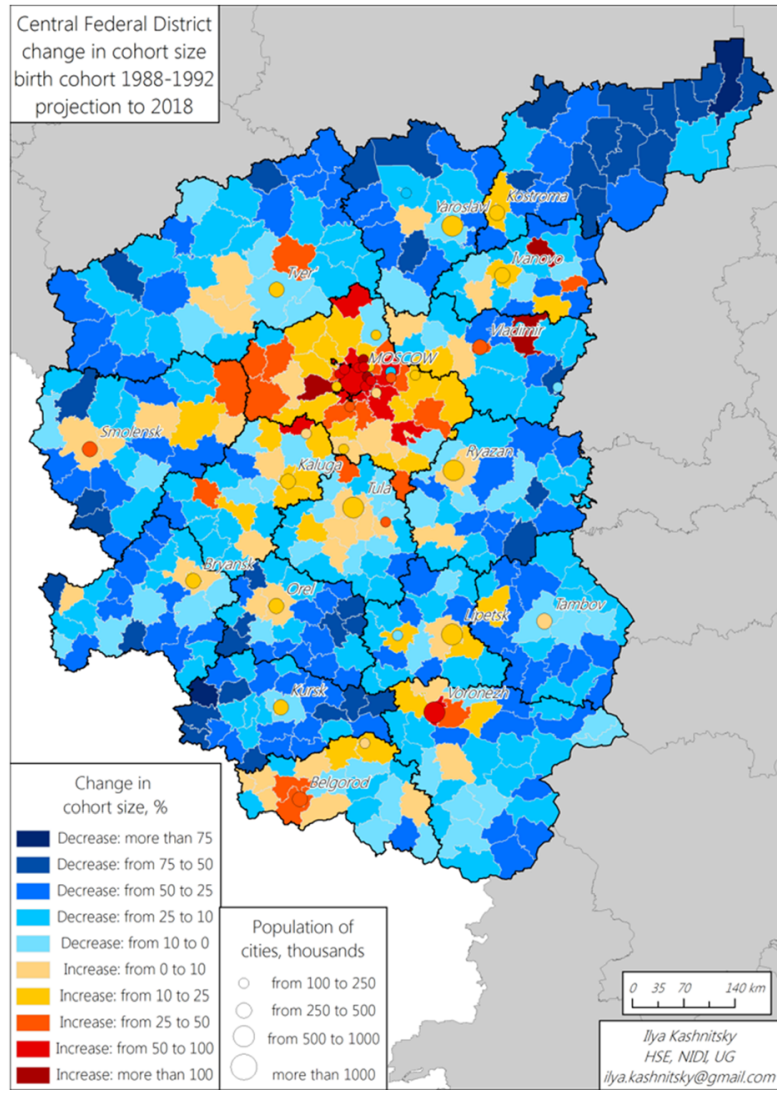

Fig. 5 Central Federal District of Russia, change in the cohort size, \%: a change in the 1980-1984 birth cohort size during 2003-2010; b projected change in the size of the 1988-1992 birth cohort during 2011-2018. Source: 2002 and 2010 Censuses

regional youth migration is likely to be quite dramatic for the inner periphery. The most depressed municipalities lose young population not only in the "student ages" but also in the "post-student ages". For example, have a look at the peripheral municipalities of Yaroslavl region in the North and Kursk region in the South. Even though non-central municipalities of these regions has lost around half of the youths in the student ages, later on these peripheral territories continue to loose young population in the ages, when some of the migrated people usually return to their previous homes. In the end, the size of the original youth cohorts shrinks by more than $70 \%$, which is an incomparably larger shrinkage than the estimated $2.8 \%$ decrease in the size of the cohort during the period of 2003-2018 due to mortality, if one assumes, as a mind experiment, no migration at all.

It's worth noting that the present estimates demonstrate an increase in the intensity of centripetal migration at the "student ages" compared to the previous intercensal period. It is likely that the intensity of intra-regional centripetal movement in "post-student ages" would also increase in the nearest future. In other words the real cohort depletion of the periphery could turn out to be even worse than the projection for the synthetic cohort.

\section{Conclusions and discussion}

In this paper I investigate internal youth migration as a factor of population dynamics at the sub-regional level. The research is conducted at the level of municipalities, revealing intra-regional migration dynamics. Analysis at such a low level of spatial disaggregation brings valuable and still quite rare insight into local level population process. 
Current statistical record proves to be an inconvenient data source for the research on internal youth migration. On average, it recorded only about one fifth of the youth migration stream to Central Federal District of Russia during the last intercensal period. The preliminary literature informed suggestion that the official migration statistics was unable to capture precisely only the "student ages" has found no empirical support, since the discrepancy was also large for the "post-student ages". A recent paper finds similar discrepances in the old-age migration (Karachurina and Mkrtchyan 2018).

Cohort research on youth migration at sub-regional level revealed the increase in the intensity of the centripetal movement in the last intercensal period compared to the previous one (Karachurina and Mkrtchyan 2015). The pace of depopulation of the hinterland is accelerating. The most depressed municipalities have lost up to $70 \%$ of school graduates during the last intercensal period. Migration proves to be the crucial factor of changes in the demographic structures at the municipal level.

Relatively small regional centers, which offer higher education but cannot offer enough employment possibilities, face a surplus of young adults in the "post-student ages" whom they are unable to hold. Thus, such cities experience an outflow of population in young working ages. This result was also found in the analysis of most recent migration statistics in Russia (Karachurina and Mkrtchyan 2018).

The depletion of the rural areas is illustrated with an exercise of projecting future "post-student age" migration to assess the possible extent of return migration. It turn out, there is no compensating return migration of young adults to the periphery. In contrast, the most depressed peripheral municipalities continue to lose population in the young working ages, even after the preceding massive outflow of school graduates. If the current rate of depopulation due to internal youth migration persists, there future demographic development of the periphery cannot be sustainable. The constant outflow of the young accelerates depopulation and ageing in the periphery. Our societies are not ready to deal with population decline (Haartsen and Venhorst 2010; Reher 2007), and depopulation areas prove to be increasingly vulnerable (Dennett 2014; Faggian et al. 2017; Rees et al. 2013). For example, rapid population decline brings the decay of social institutes, e.g. school closures (Egelund and
Laustsen 2006; Haartsen and Van Wissen 2012; Kovács 2012), which in turn bring self-reinforcing negative consequences for the local population (Elshof et al. 2014). Accelerated population ageing itself is a factor of social instability (Binstock 2010; Elshof and Bailey 2015) and may affect even the social institutes such as voting systems (Sabater et al. 2017).

The study is, of course, subject to some limitations. Issues of data availability, harmonization, and quality are the major concern. Even census data cannot be trusted blindly (Andreev 2012). Some part of the population mobility is unseen by the official migration statistics (Gunko and Nefedova 2017). The other limitation is attributable to study design. I specifically choose to focus on the age and cohort dimensions of internal youth migration, compromising on the period dimension. In other words, I treat the whole intercensal period as a single time unit. Thus period effects are not accounted for, and sometimes they can cast strong local influences on migration. For example, economic recession proves to have a notable negative impact on mobility (Sironi and Rosina 2015) and future life prospects (Lennartz et al. 2016). Sometimes, even data related issues have clear localization in time, e.g. the 2011 reform in Russian migration statistics that doubled the visible part of students' migration (Kashnitsky et al. 2016).

The impact of long-lasting migration of youths is clearly visible in the demographic structure of Russian population. The remoteness of the peripheral municipality together with the attractiveness of the regional center determines the level of the peripheral depression and rural population depletion. Every big center of migration attraction forms a depressive ring around itself. This is an evident result of "migration exhaustion". I see further avenue to build upon this study in an extensive exploit of the spatial dimension, investigating the role of distance in mediating the effect of internal youth migration of local population structures. Recent literature (Niedomysl and Fransson 2014; Niedomysl et al. 2017; Stillwell and Thomas 2016) indicate that accounting for migration distance properly may alter the estimations a lot, and the recent studies of Russian internal migration (Karachurina and Mkrtchyan 2015,2018) suggest that a notable effect of the distance of move is reasonable to expect. 
Acknowledgements Support from the Basic Research Program of the National Research University Higher School of Economics is gratefully acknowledged.

\section{Compliance with ethical standards}

Conflict of interest I declare no conflict of interests.

Open Access This article is distributed under the terms of the Creative Commons Attribution 4.0 International License (http:// creativecommons.org/licenses/by/4.0/), which permits unrestricted use, distribution, and reproduction in any medium, provided you give appropriate credit to the original author(s) and the source, provide a link to the Creative Commons license, and indicate if changes were made.

\section{References}

Abbott, W. F., \& Schmid, C. F. (1975). University prestige and first-time undergraduate migration in the United States. Sociology of Education, 48(2), 168-185. https://doi.org/10. $2307 / 2112474$.

Alho, J. M. (2008). Migration, fertility, and aging in stable populations. Demography, 45(3), 641-650. https:// doi.org/10.1353/dem.0.0021.

Andreev, E. M. (2012). O tochnisti rezultatov rossijskikh perepisei naseleniya i stepeni doveriya $\mathrm{k}$ raznim istochnikam informaysii [On the accuracy of Russian censuses and the level of reliability of various data sources]. Voprosi statistiki [Issues in statistics], 2012(11), 21-35.

Bailey, A. J. (1993). Migration history, migration behavior and selectivity. The Annals of Regional Science, 27(4), 315-326. https://doi.org/10.1007/BF01583571. Accessed November 21, 2018.

Baryla, E. A., Jr., \& Dotterweich, D. (2001). Student migration: Do significant factors vary by region? Education Economics, 9(3), 269-280. https://doi.org/10.1080/ 09645290110086135.

Beine, M., Noël, R., \& Ragot, L. (2014). Determinants of the international mobility of students. Economics of Education Review, 41(1), 40-54. https://doi.org/10.1016/j. econedurev.2014.03.003.

Bernard, A. (2017). Levels and patterns of internal migration in Europe: A cohort perspective. Population Studies, 71(3), 293-311. https://doi.org/10.1080/00324728.2017.1360932.

Binstock, R. H. (2010). From compassionate ageism to intergenerational conflict? The Gerontologist, 50(5), 574-585. https://doi.org/10.1093/geront/gnq056.

Bogue, D. (1982). Techniques of estimating net migration. Community and Family Study Center. https://www. amazon.com/Techniques-Estimating-Migration-DonaldBogue/dp/B000VZMZ3Y. Accessed November 21, 2018.

Bracken, I. (1976). Estimation and cluster analysis of net migration age profiles for urban areas in England and Wales. Regional Studies, 10(1), 53-69. https://doi.org/10. 1080/09595237600185061.

Castro, L. J., \& Rogers, A. (1983). What the age composition of migrants can tell us. Population Bulletin of the United
Nations, 15, 63-79. https://www.ncbi.nlm.nih.gov/ pubmed/12265834. Accessed November 21, 2018.

Champion, A. G. (1992). Urban and regional demographic trends in the developed world. Urban Studies, 29(3-4), 461-482. https://doi.org/10.1080/00420989220080531.

Champion, A. G., Fotheringham, S., Rees, P., Boyle, P., \& Stillwell, J. (1998). The determinants of migration flows in England: A review of existing data and evidence: $A$ report prepared for the Department of the Environment, Transport and the Regions. Newcastle upon Tyne: Department of Geography, University of Newcastle upon Tyne. http://www.geog.leeds.ac.uk/publications/Determi nantsOfMigration/report.pdf. Accessed November 21, 2018.

Choudinovskikh, O. S. (2004). O kriticheskom sostoyanii ucheta migratsii $\mathrm{v}$ Rossii [On the desperate state of migration record in Russia]. Voprosi statistiki [Issues in statistics], 2004(10), 27-36.

Choudinovskikh, O. S. (2008). Statistika migratsiji znaet ne vse (Migration statistics don't see the whole picture). Demoscope Weekly, 335-336. http://demoscope.ru/weekly/ 2008/0335/index.php. Accessed January 21, 2014.

Choudinovskikh, O. S. (2010). Sovremennoe sostoyanie statistiki migratsii v Rossii: Novie vozmozhnosti i nereshennie problemi [Contemporary state of Russian migration statistics: New opportunities and problems not yet solved]. Voprosi statistiki [Issues in statistics], 2010(6), 8-16.

Chudnovskaya, M., \& Kolk, M. (2017). Educational expansion and intergenerational proximity in Sweden. Population, Space and Place, 23(1), e1973. https://doi.org/10.1002/ psp.1973.

Ciriaci, D. (2014). Does university quality influence the interregional mobility of students and graduates? The case of Italy. Regional Studies, 48(10), 1592-1608. https://doi.org/ 10.1080/00343404.2013.821569.

Coleman, D. (2006). Immigration and ethnic change in lowfertility countries: A third demographic transition. Рориlation and Development Review, 32(3), 401-446. https:// doi.org/10.1111/j.1728-4457.2006.00131.x.

Cooke, T. J., \& Boyle, P. (2011). The migration of high school graduates to college. Educational Evaluation and Policy Analysis, 33(2), 202-213. https://doi.org/10.3102/ 0162373711399092.

Dennett, A. (2014). Quantifying the effects of economic and labour market inequalities on inter-regional migration in Europe-A policy perspective. Applied Spatial Analysis and Policy, 7(1), 97-117. https://doi.org/10.1007/s12061013-9097-4.

Domina, T. (2006). What clean break?: Education and nonmetropolitan migration patterns, 1989-2004. Rural Sociology, 71(3), 373-398. https://doi.org/10.1526/ 003601106778070626.

Dustmann, C., \& Glitz, A. (2011). Migration and education. In Handbook of the Economics of Education (Vol. 4, pp. 327-439). Elsevier. http://linkinghub.elsevier.com/ retrieve/pii/B9780444534446000043. Accessed April 19, 2014.

Ediev, D., Scherbov, S., \& Coleman, D. (2014). New measures of population reproduction for an era of high migration. Population, Space and Place, 20(7), 622-645. https://doi. org/10.1002/psp.1799. 
Egelund, N., \& Laustsen, H. (2006). School Closure: What are the consequences for the local society? Scandinavian Journal of Educational Research, 50(4), 429-439. https:// doi.org/10.1080/00313830600823787.

Elshof, H., \& Bailey, A. (2015). The role of responses to experiences of rural population decline in the social capital of families. Journal of Rural and Community Development, 10(1), 72-93. http://journals.brandonu.ca/jrcd/article/ view/1207. Accessed December 29, 2017.

Elshof, H., Van Wissen, L., \& Mulder, C. H. (2014). The selfreinforcing effects of population decline: An analysis of differences in moving behaviour between rural neighbourhoods with declining and stable populations. Journal of Rural Studies, 36, 285-299. https://doi.org/10.1016/j. jrurstud.2014.09.006.

Esteve, A., Schwartz, C. R., van Bavel, J., Permanyer, I., Klesment, M., \& García-Román, J. (2016). The end of hypergamy: Global trends and implications. Population and Development Review, 42(4), 615-625. https://doi.org/ 10.1111/padr.12012.

EuroVoc. (2017). Subregions of Europe. http://eurovoc.europa. eu/100277. Accessed September 9, 2017.

Faggian, A., Rajbhandari, I., \& Dotzel, K. R. (2017). The interregional migration of human capital and its regional consequences: A review. Regional Studies, 51(1), 128-143. https://doi.org/10.1080/00343404.2016.1263388.

Fielding, A. J. (1989). Inter-regional migration and social change: A study of South East England based upon data from the longitudinal study. Transactions of the Institute of British Geographers, 14(1), 24. https://doi.org/10.2307/ 622340.

Fielding, A. (1993). Migration and the metropolis: Recent research on the causes of migration to southeast England. Progress in Human Geography, 17(2), 195-212. https:// doi.org/10.1177/030913259301700204.

Filipov, D., \& Schuster, J. (2010). Effect of migration on population size and age composition in Europe. Vienna Institute of Demography. https://www.oeaw.ac.at/fileadmin/ subsites/Institute/VID/PDF/Publications/EDRP/edrp_ 2010_02.pdf. Accessed November 21, 2018.

Findlay, A. M. (2011). An assessment of supply and demandside theorizations of international student mobility. International Migration, 49(2), 162-190. https://doi.org/10. 1111/j.1468-2435.2010.00643.x.

Florinskaya, Y. F. (2017). School graduates from small towns in Russia: Educational and migration strategies. Studies on Russian Economic Development, 28(1), 87-96. https://doi. org/10.1134/S1075700717010038.

Florinskaya, Y. F., \& Roshchina, T. G. (2006). The migration plans of upper-grade students in small towns of Russia. Russian Education \& Society, 48(6), 44-62. http:// mesharpe.metapress.com/index/b7572612q0374431.pdf. Accessed April 20, 2014.

Franklin, R. S. (2003). Migration of the young, single, and college educated, 1995-2000. US Department of Commerce, Economics and Statistics Administration, US Census Bureau. https://usa.ipums.org/usa/resources/voliii/ pubdocs/2000/censr-12.pdf. Accessed March 8, 2017.

Franklin, R. S. (2014). An examination of the geography of population composition and change in the United States, 2000-2010: Insights from geographical indices and a shift- share analysis. Population, Space and Place, 20(1), 18-36. https://doi.org/10.1002/psp.1744.

Gunko, M., \& Nefedova, T. (2017). Coping with employment issues through commuting: Evidence from Central Russia. Moravian Geographical Reports, 25(2), 118-128. https:// doi.org/10.1515/mgr-2017-0011.

Gutiérrez-Posada, D., Rubiera-Morollón, F., \& Viñuela, A. (2018). Ageing places in an ageing country: The local dynamics of the elderly population in Spain. Tijdschrift voor economische en sociale geografie, 109(3), 332-349. https://doi.org/10.1111/tesg.12294.

Haartsen, T., \& Van Wissen, L. (2012). Causes and consequences of regional population decline for primary schools. Tijdschrift voor economische en sociale geografie, 103(4), 487-496. https://doi.org/10.1111/j.1467-9663.2012. 00736.x.

Haartsen, T., \& Venhorst, V. (2010). Planning for decline: Anticipating on population decline in the Netherlands. Tijdschrift voor economische en sociale geografie, 101(2), 218-227. https://doi.org/10.1111/j.1467-9663.2010. 00597.x.

Johansson, M. (2016). Young women and rural exodus Swedish experiences. Journal of Rural Studies, 43(1), 291-300. https://doi.org/10.1016/j.jrurstud.2015.04.002.

Johnson, K. M., Voss, P. R., Hammer, R. B., Fuguitt, G. V., \& McNiven, S. (2005). Temporal and spatial variation in agespecific net migration in the United States. Demography, 42(4), 791-812. https://doi.org/10.1353/dem.2005.0033.

Karachurina, L. B. (2014). Demographic transformation of postSoviet cities of Russia. Regional Research of Russia, 4(2), 56-67. https://doi.org/10.1134/S2079970514020087.

Karachurina, L. B., \& Mkrtchyan, N. V. (2015). Population change in the regional centres and internal periphery of the regions in Russia, Ukraine and Belarus over the period of 1990-2000s. Bulletin of Geography. Socio-economic Series No, 28(1), 91-111. https://doi.org/10.1515/bog-20150018 .

Karachurina, L. B., \& Mkrtchyan, N. V. (2018). Age-specific net migration patterns in the municipal formations of Russia. GeoJournal, 83(1), 119-136. https://doi.org/10.1007/ s10708-016-9757-4.

Kashnitsky, I. (2015). Youth migration drives the depopulation of periphery. In XV April international academic conference on economic and social development (Vols. 1-4, Vol. 3, pp. 103-113). Moscow: Higher School of Economics.

Kashnitsky, I., Mkrtchyan, N., \& Leshukov, O. (2016). Interregional migration of youths in Russia: a comprehensive analysis of demographic statistics. Educational Studies Moscow, 13(3), 169-203. https://doi.org/10.17323/18149545-2016-3-169-203.

Kovács, K. (2012). Rescuing a small village school in the context of rural change in Hungary. Journal of Rural Studies, 28(2), 108-117. https://doi.org/10.1016/j.jrurstud.2012.01. 020.

Lennartz, C., Arundel, R., \& Ronald, R. (2016). Younger adults and homeownership in europe through the global financial crisis. Population, Space and Place, 22(8), 823-835. https://doi.org/10.1002/psp.1961.

Millington, J. (2000). Migration and age: The effect of age on sensitivity to migration stimuli. Regional Studies, 34(6), 521-533. https://doi.org/10.1080/00343400050085648. 
Mkrtchyan, N. V. (2013). Migration of young people to regional centers of Russia at the end of the 20th and the beginning of the 21st centuries. Regional Research of Russia, 3(4), 335-347. https://doi.org/10.1134/S2079970513040096.

Moiseenko, V. M. (2004). Vnutrennyaya migratsiya naseleniya [Internal migration of population]. Moscow: TEIS.

Mulder, C. H., \& Clark, W. A. V. (2002). Leaving home for college and gaining independence. Environment and Planning A, 34(6), 981-999. https://doi.org/10.1068/ a34149.

Ní Laoire, C. (2007). The "green green grass of home"? Return migration to rural Ireland. Journal of Rural Studies, 23(3), 332-344. https://doi.org/10.1016/j.jrurstud.2007.01.005.

Niedomysl, T., Ernstson, U., \& Fransson, U. (2017). The accuracy of migration distance measures. Population, Space and Place, 23(1), e1971. https://doi.org/10.1002/ psp. 1971.

Niedomysl, T., \& Fransson, U. (2014). On distance and the spatial dimension in the definition of internal migration. Annals of the Association of American Geographers, 104(2), 357-372. https://doi.org/10.1080/00045608.2013. 875809.

Patiniotis, J., \& Holdsworth, C. (2005). "Seize that chance!" Leaving home and transitions to higher education. Journal of Youth Studies, 8(1), 81-95. https://doi.org/10.1080/ 13676260500063710.

Pittenger, D. B. (1974). A typology of age-specific net migration rate distributions. Journal of the American Institute of Planners, 40(4), 278-283. https://doi.org/10.1080/ 01944367408977480.

Plane, D. A., Henrie, C. J., \& Perry, M. J. (2005). Migration up and down the urban hierarchy and across the life course. Proceedings of the National Academy of Sciences, 102(43), 15313-15318. https://doi.org/10.1073/pnas.0507312102.

Preston, S. H., Heuveline, P., \& Guillot, M. (2001). Demography: Measuring and modeling population processes. Oxford: Blackwell Publishers.

Rauhut, D., \& Littke, H. (2016). “A one way ticket to the city, please!" On young women leaving the Swedish peripheral region Västernorrland. Journal of Rural Studies, 43(1), 301-310. https://doi.org/10.1016/j.jrurstud.2015.05.003.

Ravenstein, E. G. (1885). The Laws of Migration. Journal of the Statistical Society of London, 48(2), 167-235. https://doi. org/10.2307/2979181.

Raymer, J., Smith, P. W. F., \& Giulietti, C. (2011). Combining census and registration data to analyse ethnic migration patterns in England from 1991 to 2007. Population, Space and Place, 17(1), 73-88. https://doi.org/10.1002/psp.565.

Rees, P., Bell, M., Kupiszewski, M., Kupiszewska, D., Ueffing, P., Bernard, A., et al. (2017). The impact of internal migration on population redistribution: An international comparison. Population, Space and Place, 23(6), e2036. https://doi.org/10.1002/psp.2036.

Rees, P., Zuo, C., Wohland, P., Jagger, C., Norman, P., Boden, P., et al. (2013). The implications of ageing and migration for the future population, health, labour force and households of northern England. Applied Spatial Analysis and Policy, 6(2), 93-122. https://doi.org/10.1007/s12061-0139086-7.

Reher, D. S. (2007). Towards long-term population decline: A discussion of relevant issues: Vers un déclin à long terme de la population: Discussion des questions pertinentes. European Journal of Population/Revue européenne de Démographie, 23(2), 189-207. https://doi.org/10.1007/ s10680-007-9120-z.

Rérat, P. (2014). Highly qualified rural youth: Why do young graduates return to their home region? Children's Geographies, 12(1), 70-86. https://doi.org/10.1080/ 14733285.2013.850849.

Sabater, A., Graham, E., \& Finney, N. (2017). The spatialities of ageing: Evidencing increasing spatial polarisation between older and younger adults in England and Wales. Demographic Research, 36(25), 731-744. https://doi.org/10. 4054/DemRes.2017.36.25.

Sironi, E., \& Rosina, A. (2015). Leaving the parental home in Italy during the economic crisis. Genus, 71(2-3), 199-216. https://doi.org/10.4402/genus-685.

Smith, D. P., Rérat, P., \& Sage, J. (2014). Youth migration and spaces of education. Children's Geographies, 12(1), 1-8. https://doi.org/10.1080/14733285.2013.871801.

Stillwell, J., \& Thomas, M. (2016). How far do internal migrants really move? Demonstrating a new method for the estimation of intra-zonal distance. Regional Studies, Regional Science, 3(1), 28-47. https://doi.org/10.1080/21681376. 2015.1109473.

Thissen, F., Fortuijn, J. D., Strijker, D., \& Haartsen, T. (2010). Migration intentions of rural youth in the Westhoek, Flanders, Belgium and the Veenkoloniën, The Netherlands. Journal of Rural Studies, 26(4), 428-436. https:// doi.org/10.1016/j.jrurstud.2010.05.001.

Thomas, D. S. (1938). Research memorandum on migration differentials: With contrib. By Rudolf Heberle. A report of the Committee on Migration Differentials.

Van Der Gaag, N., \& Van Wissen, L. (2001). Determinants of the subnational distribution of immigration. Tijdschrift voor Economische en Sociale Geografie, 92(1), 27-41. https://doi.org/10.1111/1467-9663.00137.

Van Mol, C., \& Timmerman, C. (2014). Should I stay or should I go? An analysis of the determinants of intra-European student mobility. Population, Space and Place, 20(5), 465-479. https://doi.org/10.1002/psp.1833.

Venhorst, V., Van Dijk, J., \& Van Wissen, L. (2011). An analysis of trends in spatial mobility of Dutch graduates. Spatial Economic Analysis, 6(1), 57-82. https://doi.org/10. 1080/17421772.2010.540033.

Wilson, T. (2010). Model migration schedules incorporating student migration peaks. Demographic Research, 23(8), 191-222. https://doi.org/10.4054/DemRes.2010.23.8.

Wilson, C., Sobotka, T., Williamson, L., \& Boyle, P. (2013). Migration and intergenerational replacement in Europe. Population and Development Review, 39(1), 131-157. https://doi.org/10.1111/j.1728-4457.2013.00576.x.

Wunsch, G. J., \& Termote, M. (1978). Introduction to demographic analysis: Principles and methods. New York: Plenum Press.

$\mathrm{Xu}, \mathrm{Z}$. (2014). Spatial and longitudinal patterns in county agespecific net migration in the United States 1950-2010. The Professional Geographer, 66(4), 641-652. https://doi.org/ 10.1080/00330124.2013.868690.

Zayonchkovskaya, Z. A. (1991). Demograficheskaya situstsiya $i$ rasselenie [Demographis and Settlement Pattern]. Moscow: Nauka. 